\title{
THE EFFECT OF A REMEDATION PROGRAM FOR DRUG SAFETY IMPLEMENTATIONS FOLLOWED BY NURSES IN OUTPATIENT CLINICS
}

\author{
N. AYDOĞAN ${ }^{1}$, G. ALKAN ${ }^{1}$, S. KOÇi' ${ }^{1}$, I. ALKAN ${ }^{2}$, N. BORA GÜNEŞ \\ ${ }^{1}$ Hacettepe University, İhsan Doğramacı Children's Hospital, Ankara, Turkey. \\ ${ }^{2}$ Hacettepe University, Nursing Faculty Pediatric Nursing Department, Ankara, Turkey.
}

\section{Background and Aims}

Unwanted events related to drugs occur frequently and can be prevented by adequate precautions. We conducted this study in order to determine the effect of a remedation program for some aspects of safety implementations followed by nurses among outpatient clinics.

\section{Method}

We performed a pretest-posttest design, experimental study, including a survey of nurses and a chart review, and a remedation program at 10 pediatric outpatient clinics in a university hospital. The survey for nurses and chart rewiev include questions for drug storage informations including narcotics, labels, emergency cart, verbal medical orders and records. The questions were prepared according to Joint Commission International on Accreditations of Healthcare Organizations (JCAHO) Standards by the researchers. A remadation program was established by multidiciplinary drug safety and management commission of the hospital according to the literature. It involves an electronic drug system for management the drug usage and verbal orders. Pre-posttest were implemented in threedifferent times.

\section{Results}

All of the narcotics were locked, ruining was recorded and prescriptons were adequate (table 1 ). The refrigirator heat was recorded (81.6\%) and locked (63.2\%), drugs were labeled (\%63.2) in most of the outpatient clinics (table 2). Verbal medical order protocol was obeyed (71.1\%) and they were recorded $(84.2 \%)$ by most of the nurses (table 3$)$. After the program was implemented the survey was repeated. The participants demonstrated significantly higher rates to obey the safety precautions after the implementation $(p<0,05)$. Posttest datas were collected one month after the remedation programme. Acording to the posttest results the refrigirator heat was recorded (84.2\%) and locked (71.1\%), drugs were labeled (\%81.6) in most of the outpatient clinics (table 2). Verbal medical order protocol was obeyed (81.6\%) and they were recorded (94.7\%) by most of the nurses (table 3 ).

\section{Conclusion}

The results suggest that JCAHO drug Safety Event Taxonomy could facilitate a common approach for drug safety information systems. The supervision and digital systems could also facilitate the awareness for the precautions.
Table 1 Status of the nurses' obeying narcotic safety precautions

\begin{tabular}{|r|r|c|c|c|c|}
\hline & & \multicolumn{2}{|c|}{ Pretests } & \multicolumn{2}{c|}{ Posttests } \\
\hline & & $n$ & $\%$ & $n$ & $\%$ \\
\hline Locking narcotics & Yes & 38 & 100.0 & 38 & 100.0 \\
\hline $\begin{array}{r}\text { Adequate } \\
\text { narcotic }\end{array}$ & Yes & 38 & 100.0 & 38 & 100.0 \\
\hline prescription & & 0 & 0.0 & 0 & 0.0 \\
\hline Total & No & 0 & 0.0 & 0 & 0.0 \\
\hline
\end{tabular}

Table 2 Status of the nurses' obeying drug storage precautions

\begin{tabular}{|c|c|c|c|c|c|c|}
\hline & & \multicolumn{2}{|c|}{ Pretests } & \multicolumn{3}{|c|}{ Posttests } \\
\hline & & $n$ & $\%$ & $n$ & $\%$ & $p$ \\
\hline \multirow[t]{2}{*}{ Adequate storage } & Yes & 12 & 31.6 & 24 & 63.2 & \multirow[t]{2}{*}{$0.00 *$} \\
\hline & No & 26 & 68.4 & 14 & 36.8 & \\
\hline \multirow[t]{2}{*}{$\begin{array}{r}\text { Refrigirator heat } \\
\text { record }\end{array}$} & Yes & 31 & 81.6 & 32 & 84.2 & \multirow[t]{2}{*}{$0.03^{*}$} \\
\hline & No & 7 & 18.4 & 6 & 15.8 & \\
\hline \multirow[t]{2}{*}{$\begin{array}{r}\text { Locking } \\
\text { refrigirator }\end{array}$} & Yes & 24 & 63.2 & 27 & 71.1 & \multirow[t]{2}{*}{$0.00^{*}$} \\
\hline & No & 14 & 36.8 & 11 & 28.9 & \\
\hline \multirow[t]{2}{*}{ Drug label } & Yes & 23 & 60.5 & 31 & 81.6 & \multirow{2}{*}{$0.00 *$} \\
\hline & No & 15 & 39.5 & 7 & 18.4 & \\
\hline Total & & 38 & 100.0 & 38 & 100.0 & \\
\hline
\end{tabular}

Table 3 Status of the nurses' obeying verbal medical order precautions

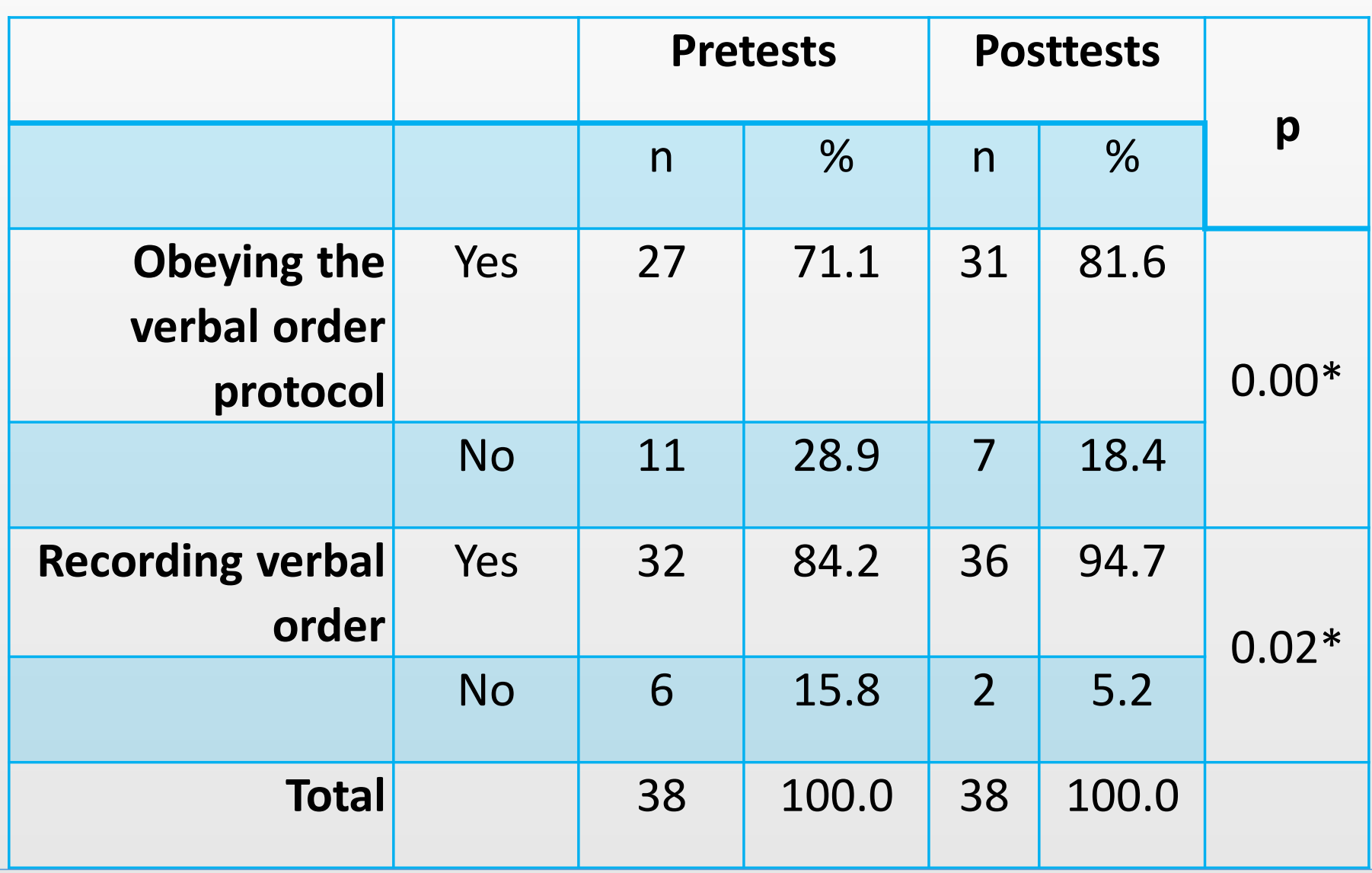

\section{References}

1. Locquet, M., Honvo, G., Rabenda, V., Van Hees, T., Petermans, J., Reginster, J. Y., \& Bruyère, O. (2017). Adverse health events related to selfmedication practices among elderly: a systematic review. Drugs \& aging, 34(5), 359-365.

2. Peddie, D., Small, S. S., Badke, K., Wickham, M. E., Bailey, C., Chruscicki, A., ... \& Hohl, C. M. (2016). Designing an adverse drug event reporting system to prevent unintentional reexposures to harmful drugs: study protocol for a multiple methods design. JMIR research protocols, 5(3).

3. Kovshoff, H., Banaschewski, T., Buitelaar, J. K., Carucci, S., Coghill, D., Danckaerts, M., ... \& Inglis, S. (2016). Reports of perceived adverse events of stimulant medication on cognition, motivation, and mood: qualitative investigation and the generation of items for the Medication and Cognition Rating Scale. Journal of child and adolescent psychopharmacology, 26(6), 537-547. 